\title{
SALIENCE AND ACCOUNTABILITY: SCHOOL INFRASTRUCTURE AND LAST-MINUTE ELECTORAL PUNISHMENT
}

\author{
Nicolás Ajzenman \\ Ruben Durante
}

\section{LATIN AMERICAN AND THE CARIBBEAN ECONOMIC ASSOCIATION}

February 2020

The views expressed herein are those of the authors and do not necessarily reflect the views of the Latin American and the Caribbean Economic Association. Research published in this series may include views on policy, but LACEA takes no institutional policy positions.

LACEA working papers are circulated for discussion and comment purposes. Citation of such a paper should account for its provisional character. A revised version may be available directly from the author.

(C) 2020 by Nicolás Ajzenman and Ruben Durante. All rights reserved. Short sections of text, not to exceed two paragraphs, may be quoted without explicit permission provided that full credit, including (C) notice, is given to the source. 
LACEA WORKING PAPER SERIES No. 0039 February 2020

Salience and Accountability: School Infrastructure and Last-Minute Electoral Punishment

Nicolás Ajzenman

Sao Paulo School of Economics-FGV

nicolas.ajzenman@fgv.br

\author{
Ruben Durante \\ ICREA, Universitat Pompeu Fabra, Barcelona GSE, IPEG, and CEPR \\ ruben.durante@upf.edu
}

\begin{abstract}
Can seemingly unimportant factors influence voting decisions by making certain issues salient? We study this question in the context of Argentina 2015 presidential elections by examining how the quality of the infrastructure of the school where citizens were assigned to vote influenced their voting choice. Exploiting the quasi-random assignment of voters to ballot stations located in different public schools in the city of Buenos Aires, we find that individuals assigned to schools with poorer infrastructure were significantly less likely to vote for Mauricio Macri, the incumbent mayor then running for president. The effect is larger in low-income areas - where fewer people can afford private substitutes to public education - and in places where more households have children in school age. The effect is unlikely to be driven by information scarcity, since information on public school infrastructure was readily available to parents before elections. Rather, direct exposure to poor school infrastructure at the time of voting is likely to make public education - and the poor performance of the incumbent - more salient.
\end{abstract}

JEL Classification: D72, D83, I25, D90.

Keywords: Elections, Salience, Electoral Punishment, Public Infrastructure, Education.

\title{
ACKNOWLEDGEMENTS AND FINANCIAL DISCLOSURE
}

We thank Roberto Galbiati, Sergei Guriev, Filipe Campante, Quoc-Anh Do, Claudia Senik, Razcan Vlaicu, Ralph De Haas, Bernardo Guimaraes, Agustin Casas, Carlos Scartascini and seminar participants at the LACEA-LAMES 2019's annual meeting and the first LACEA-Brain meeting for helpful comments. 


\section{Introduction}

Being informed about government actions is crucial for voters to correctly evaluate politicians and punish or reward them come election time. Yet, though information about government performance is widely available, evidence suggests that voters do not always translate it into useful knowledge. For example, they can mistakenly infer politicians' quality from their performance (e.g., attributing the effect of luck to effort Healy et al. (2010)), or can be swayed by seemingly irrelevant factors such as the order of the names on the ballot (Blom-Hansen et al., 2016).

Whether these lapses are due to the frictional costs associated with information processing or to the existence of mental gaps (Handel and Schwartzstein, 2018), the form and context in which information is presented to voters is also likely to matter. Indeed, prior findings suggest that information provided in a more visible way and at the appropriate time can have a larger effect on individuals' decision-making process (DellaVigna, 2009; Mani and Mukand, 2007; Harding and Stasavage, 2013; Robinson and Torvik, 2005).

In this paper we investigate to what extent exposure to information about government performance at the time of voting affects voters' electoral choices by making certain issues more salient. Focusing on the issue of public education and school infrastructure quality, we study whether voters assigned to vote in schools with poorer infrastructure are less likely to support the incumbent. Specifically, we test the hypothesis that being directly exposed to the poor state of public schools at the time of voting, makes the issue of public education more salient and voters more likely to punish the incumbent government for its inadequate performance in the provision of this key public good.

Our analysis focuses on the presidential elections held in Argentina in 2015 which, for various reasons, represent a particularly suitable context to study this question. First, one of the main candidates running for president was Mauricio Macri, until then mayor of Buenos Aires. As mayor, Macri had been in charge of the city's public school system for the prior eight years, and could therefore be considered responsible for the state of local public schools. Indeed, the issue of public education, and the promise of more investments in public schools, had been a cornerstone of Macri's campaign for mayor and then for president. ${ }^{1}$ Furthermore, the improvement of Buenos Aires public education system achieved under his tenure, was regularly praised by his presidential campaign. ${ }^{2}$

\footnotetext{
${ }^{1}$ For example, Macri's commitment to improve the quality of Argentina's early education system and to build 3,000 new kindergartens once elected president, received extensive media coverage during the 2015 campaign. See for example: https://www.bigbangnews.com/politica/campana-kinder-macri-prometio-3000nuevos-jardines-de-infantes-2015-9-4-5-33-0.

${ }^{2}$ See, for instance: https://chequeado.com/ultimas-noticias/macri-aumenta-sistematicamente-la-
} 
The second aspect, which is key to our identification strategy, concerns the way Argentinian voters are assigned to vote in particular ballot stations located, without exception, in schools. Indeed, within each of the narrow electoral circuits ${ }^{3}$ in which each electoral district is divided, voters are assigned to ballot stations based on the alphabetical order of their last name. Exploiting the quasi-random nature of this procedure, we try to gauge the causal impact of exposure to school infrastructure, by comparing the electoral behavior of voters assigned to schools in good vs. bad infrastructural conditions. What is key for our identification strategy is that the distribution of last names is not systematically correlated with the quality of school infrastructure within circuits. Indeed, even if the frequency of certain last names was correlated with some observable or unobservable voters' characteristics (e.g., if last names starting with the letter A were more common among rich than among poor people), we would still identify a causal effect as long as these characteristics are not systematically correlated with school quality within circuit (e.g., if voters with last names starting in A are not assigned to schools with better infrastructure).To corroborate this assumption, using data on voters' age and gender at the ballot station level, we document that, at least along these dimensions, voters assigned to schools with good infrastructure are similar to those assigned to schools with poorer infrastructure.

Following this approach, and using comprehensive ballot-station level data for the entire city of Buenos Aires, we find that voters assigned to "poor-infrastructure" schools are significantly less likely to support Macri than those voting in "good-infrasctructure" ones. On average, exposure to poor school infrastructure is associated with a decrease in Macri's vote share of 0.22 percentage points. ${ }^{4}$ The effect is mainly concentrated in areas populated by voters that value or benefit disproportionately from public schools. These include lowincome circuits, where fewer people can afford private substitutes to public education (effect between 0.49-0.53 p.p.), and areas with a higher share of households with kids in school age (0.52-0.60 p.p.). The effect reaches its peak - 0.58-0.67 p.p. - in places with both these characteristics. This pattern suggests that the increased salience of public school infrastructure is especially effective at shaping the voting choice of those individuals that have a higher stake in the provision of this public good. This result is also informative with respect to the possible mechanism(s) through which the effect may operate. Indeed, since the groups that are most affected by the experience at the polling booth are also more likely to be aware of the quality of public schools in their community even before the election, it seems unlikely that the effect may be solely due to the availability of new information. Rather, experiencing

matricula-de-la-escuela-publica-de-la-ciudad/.

${ }^{3}$ Electoral circuits could be thought as neighborhoods, there are 169 of them in the City of Buenos Aires.

${ }^{4}$ To put this number in context, the last polls before the different election rounds estimated between $11 \%$ and $20 \%$ of undecided voters. See, for example Elypsis, Perfil and La Nacion. 
poor school infrastructure so visibly minutes before casting their ballot, is likely to make the issue salient to voters right around the time their final decision is made. Consistent with this hypothesis, we also show that the effect is identical whether people live relatively closer to the schools were they vote (and thus, that are more likely that have already passed by them) or farther away.

We find no effect of school infrastructure quality on both voter turnout and on the proportion of invalid vote. The non-result on turnout is reassuring that the effect is indeed driven by exposure to school infrastructure and not by other confounds, since voters can witness the quality of the school premises once at the voting booth and not before. To the extent that invalid ballots are considered a form of protest vote (Power and Garand (2007)), this non-result indicates, instead, that voters' direct their disappointment with the quality of public schools specifically to the former mayor and not to the political establishment in general.

All the above-mentioned results are robust to different specifications and to the inclusion of a range of controls both at the school and at the polling booth level. Taken together, these findings support the view that making information about public policy salient can have a significant impact on the way voters evaluate government performance and, ultimately, on their ability to keep elected officials accountable.

Our paper relates to several strands of literature. First, it is related to previous work on the impact of contextual factors on voters' decision-making at the polling station (see Shue and Luttmer (2009), Berger et al. (2008), Marcinkiewicz (2014), Koppell and Steen (2004), Miller and Krosnick (1998), among others). Unlike these contributions, however, we ascribe the documented effect not to unconscious factors (or behavioral confusion, such as Shue and Luttmer (2009)) but to increased attention to the issue of public education triggered by the salience of school quality in the polling station, as hinted by the fact that the effect is driven by those individuals that have a greater stake in the quality of schools.

In this regard, our findings also relate to the literature on attention scarcity, limited attention and salience (DellaVigna (2009), Gabaix (2017)). Information regarding government's performance is readily available and people are constantly exposed to events that signal the quality of the municipal government: the quality of parks, the cleanliness of the street and even the quality of public schools' infrastructure when parents pick up their children. However, incorporating and processing information is costly especially when it is not sufficiently salient. Under such circumstances, the context and the form (i.e., more or less salient) in which information is presented matters (DellaVigna (2009), Kamenica (2012)). Making the quality of public school infrastructure salient in the exact moment at which citizens had to decide their votes seemed to affect their voting behaviour, regardless of their past exposure 
to information signaling the quality of the government. ${ }^{5}$

Second, this paper relates to previous work on the effect of the visibility of public spending on voting behaviour. This literature has documented that democratic governments tend to bias resource allocation towards more visible investments because voters may overweight the importance of these kinds of policies when assessing the performance of the government (Mani and Mukand (2007), Harding and Stasavage (2013), Robinson and Torvik (2005)). Our findings contribute to this literature by showing that voters effectively react by punishing politicians when they are exposed to a visible government outcome, such as schools' infrastructure. This paper corroborates the idea that, from a politician's point of view, spending money in particular and visible inexpensive actions before the election (such as fixing the schools or, maybe, cleaning the areas close to the voting centers) could have a significant electoral return.

Finally, this paper relates to the literature on political agency (Ferejohn (1986), Besley (2007), Barro (1973), Duggan and Martinelli (2017)) and electoral accountability (Ashworth (2012), Banerjee et al. (2011), Pande (2011), Nannicini et al. (2013), Drago et al. (2014), Casas et al. (2017)). The hypothesis of retrospective voting has been tested in the context of variations in specific public policies (Casaburi and Troiano (2015), Drago et al. (2017), Brender (2003), Brender and Drazen (2008), Alesina et al. (2012)) and in the context of variation in voters' access to new information (Dias and Ferraz (2017), Ferraz and Finan (2008), Ferraz and Finan (2008), Chong et al. (2014), Larreguy et al. (2015)). This paper shows that, though voters use past information on governments' performance evaluate them and decide their vote (as retrospective voting theories suggest), processing information is costly and therefore small pieces of information delivered at the precise moment could have a disproportionate effect on their assessment.

The reminder of the paper is structured as follows: Section 2 explains the institutional background, Section 3 describes the data, Section 4 discusses the empirical strategy, Section 5 presents the main results and interpretation, and concluding remarks follow in Section 6 .

\footnotetext{
${ }^{5}$ This notion is related to the papers on the effects on salience under attention scarcity in different fields. DellaVigna and Pollet (2009), for example, show that financial markets have a stronger reaction to new information when the news are published any day of the week other than Friday, when investors are more distracted. Chetty et al. (2009) show that the demand for a certain product falls when the sales tax is salient (i.e., included in the price tag), Hossain and Morgan (2006) show that the average sale price of two equivalent auctions on eBay may differ depending on how salient the shipping cost is from the consumer's point of view, Finkelstein (2009) shows that toll rates become higher when drivers start to use electronic tolls systems, which make the payment less salient. Our paper contributes to this literature by showing how inattention can also have a significant effect on people's voting decisions.
} 


\section{Institutional Background}

\subsection{Presidential Elections}

Argentina is a presidential democracy in which the president is directly elected by popular vote every four years. To become president a candidate must obtain a qualified majority of $45 \%$ or obtain at least $40 \%$ of the votes with a difference of $10 \%$ or more over the candidate in second position. If none of these conditions is met, a runoff election is held between the top two candidates and the one obtaining more votes is elected president. An important feature of the Argentinian system is that voting is compulsory for anyone aged 18 to 69 (optional for indivdiuals aged 16 to 17 and older than 69). Therefore, turnout for presidential elections is typically high, around $80 \%$ for each of the last five presidential elections. ${ }^{6}$

In 2011, a new system to elect candidates running in the general elections was introduced. Until then, every party was free to select its candidates using its preferred method, whether through primaries or through internal discussion. The new system, called PASO (the Spanish acronym for Simultaneous and Mandatory Open Primaries), require parties to select candidates through open primaries. Like for general elections, participation in the PASO elections is compulsory for all citizens . All of the primaries are held simultaneously. Therefore, in every presidential PASO, each party presents a list of candidates, and voters choose their preferred candidate. The setting is identical to that of a general election, with the only difference that parties present more than one candidate. The candidate who obtains the simple majority within each party will be the one competing in the general election for that party or coalition of parties. Only parties that obtain more than $1.5 \%$ of the votes in the PASO elections are eligible to participate in the general election.

The law does not force parties to present more than one candidate, and, in practice, many parties have only one. Given that it is mandatory (and turnout rates are normally high), both the parties and the media generally consider the PASO almost as important as the general election, and the results of the PASO often very accurately predict the results in the subsequent election, which typically occurs a few months later.

\subsection{The 2015 presidential election}

The last presidential election held in Argentina was in 2015. The PASO elections took place in August and the first round of the general elections in October, with the runoff in November. Eleven parties presented candidates for the primaries, although five of the parties

\footnotetext{
${ }^{6}$ See https://www.idea.int for a regional comparison.
} 
obtained less than $1 \%$ of the votes and did not make it to the general election. The main competing parties are described in the Appendix in Section 8.1. Also in the Appendix, Figure 4 shows the results of the three elections at the national level.

In 2015, one of the favorite candidates was the Governor of the Province of Buenos Aires, Daniel Scioli, running for Frente para la Victoria (FPV, in charge of the Federal Government since 2003). The main opposition leader was Mauricio Macri, the mayor of the City of Buenos Aires since 2007 (from Cambiemos, a modern center-right party).

Citizens of the City of Buenos Aires, therefore, had the chance to punish or reward the candidate who had been in charge of the city for the past eight years and was now aspiring to be president. The results were very tight throughout the electoral process: in the PASO elections, FPV obtained $38 \%$ of the votes versus $30 \%$ for Cambiemos; in the first round of the general election, FPV obtained $37 \%$ of the votes versus $34 \%$ for Cambiemos; and in the runoff, Cambiemos won the election with $51.3 \%$ of the votes versus FPV's $48.7 \%$. Mauricio Macri became President in December 2015.

\subsection{The role of Mayors}

Argentina is a federal democracy with three levels of government: federal, provincial and municipal (ruled by directly elected president, governors and mayors, respectively). There are 23 provinces plus the City of Buenos Aires, which is autonomous but identical to a province in almost all the relevant aspects. The mayor of Buenos Aires is, therefore, the equivalent of any other governor in the country.

The responsibility of sub-national governments (such as the City of Buenos Aires) for the provision of public goods and services significantly increased after a decentralization process beginning in the early 1990's. For example, before the reforms the federal government managed around $44 \%$ of all high schools and $2 \%$ of primary schools, whereas in 1994, it was no longer in charge of any schools (except for a few particular high schools that were part of the national public universities), ${ }^{7}$ and sub-national governments managed all of the public schools located within their geographical boundaries.

As a consequence of the decentralization process, expenses related to education became one of the most significant items of any provincial budget (or, in this case, of the City's budget): around a third, on average (Rivas and Dborkin (2018)). In the City of Buenos Aires, between $23 \%$ and $30 \%$ of public expenditures have been dedicated to education since then, and it represents the biggest single budget item, followed closely by health care, and well above any other line of spending. Thus, education has become one of the most relevant

\footnotetext{
${ }^{7}$ See http://www.bnm.me.gov.ar/giga1/documentos/EL004000.pdf, in Spanish
} 
responsibilities of the city's mayor and the quality of education and schooling infrastructure reveals useful information about the effectiveness of the local government and its budget priorities. $^{8}$

The quality of the educational infrastructure has historically been a concern of the people of the City of Buenos Aires, and the issue is typically reflected in the policies and campaign promises of the different mayors. As an example, in November 2007, one month before assuming control of the local government, Mauricio Macri ran a schooling infrastructure survey and concluded that two thirds of the schools were in a critical state. The results rapidly reached the media ${ }^{9}$ and were used to push the local congress to officially declare a state of infrastructural emergency in a law that passed during the Macri government's first week. This law allowed the government to be more discretionary in terms of the funds allocated to improving the infrastructural conditions of public schools.

Although there has been a substantial improvement in the quality of school infrastructure (less than $15 \%$ of the schools were declared in very bad or critical condition in 2015, for example), it still remains an important concern for the citizens. Almost every year since 2007, massive teachers' strikes and students' demonstrations have taken place to demand better infrastructure. ${ }^{10}$

\subsection{The voting process}

In Argentina, people vote at polling booths in pre-assigned voting "precincts", which are typically classrooms within schools located in the circuit in which they live. For electoral purposes, the country is divided into 24 districts (the 23 provinces plus the City of Buenos Aires), which are further divided into sections (geographical units normally smaller than municipalities) and then these into circuits. ${ }^{11}$ Each province is in charge of proposing the limits of the circuits in their territories according to the distribution of the population, and these limits rarely change.

In Buenos Aires, there are approximately 2.5 million registered voters divided into 167 electoral circuits, as Figure 1 shows (thin line divides circuits). Citizens cast their votes in more than 7,300 different polling booths located in approximately 800 different schools. Figure 1 also shows the distribution of schools in each of the 167 circuits of the city.

\footnotetext{
${ }^{8}$ Citizen security is also one of the most important items in the sub-national budgets. However, in the case of Buenos Aires, until 2016, the local police were funded and managed by the Federal Government.

${ }^{9}$ See for instance here.

${ }^{10}$ These strikes became really notorious and tended to reach the media very easily. For example: "Thirteen public schools remain on strike (2015)", "The strike in Mariano Moreno school continues (2010)", "Fourteen schools have been taken over by students (2011)".

${ }^{11}$ See here.
} 


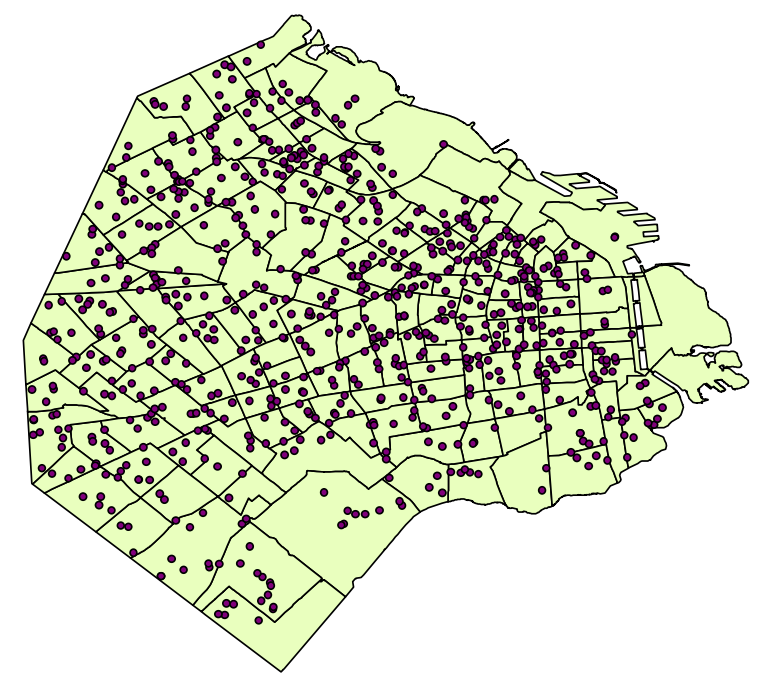

Source: Buenos Aires Data and La Nacion

Each polling booth within a circuit and a school receives a fixed number of registered electors. Within each electoral circuit, voters are then grouped into different polling booths (normally classrooms located inside schools) in alphabetical order. For example, within circuit 1, polling booth 1 receives the first $\mathrm{X}$ electors according to the alphabetical list of that circuit; polling booth 2 receives electors from position $\mathrm{X}+1$ to $\mathrm{Y}$; and so on (see Casas et al. (2017) for a detailed explanation of the process). Therefore, the allocation of voters to schools is completely random once the electoral circuit is accounted for. The allocation of voters into polling booths does not change between electoral rounds in a given year and rarely changes between electoral years (i.e., an individual who voted in a certain school in the 2015 election probably voted in the same one in 2017 and did not go to a different polling booth between the PASO and the first or second round of the general election).

\section{Data and Sample}

We focus on the 2015 Presidential Election in Argentina and use information from the three electoral rounds held between August and November 2015. Due to data availability, the analysis is limited to the City of Buenos Aires, but the context is, nonetheless, particularly suitable for our analysis, as we are able to measure the electoral reward or punishment of the presidential candidate who was previously the mayor of the city. Electoral data come 
from the Cámara Nacional Electoral (CNE), the official agency in charge of counting and compiling the results. The CNE is a federal institution, part of the Judicial Branch, and is responsible of organizing each step of the electoral process, including the counting and publication of the results. The dataset contains the total number of voters, the number of registered electors in each polling booth, the number of valid votes and the votes received for every candidate and party, throughout each of the electoral rounds (PASO, first and second rounds of general elections). As a main dependent variable, we use the proportion of votes for Mauricio Macri in the 2015 election. We use only the votes cast in public schools (for which data on public infrastructure are readily available). Table 1 shows descriptive statistics of each of the rounds, calculated at the "precinct" (i.e., school) level.

The main explanatory variable is the quality of public infrastructure, measured at the school level. Our sample is composed by 456 public schools distributed across 158 electoral circuits. The dataset contains information gathered by the General Directorate of School Infrastructure between 2015 and 2016. This office keeps a record showing the name of each public school (which is used for internal purposes and does not become public), its address and a score ranging from 1 to 4 (Very bad, Bad, Good, Very good) indicating its infrastructure condition. Unfortunately, the data were designed for their internal purposes only, so is not detailed enough to distinguish between different types of infrastructural problems (i.e., more or less visible).

Figure 2 shows the distribution of schools by type according to their infrastructural quality. ${ }^{12}$ Table 2 shows the descriptive statistics of the electoral outcomes by type of school.

We also got access to an individual-level dataset containing the gender of all the registered voters of the City of Buenos Aires, the polling booth they were assigned to vote and the age in case they were male (age for female voters is missing). ${ }^{13}$

The final dataset is, therefore, a combination of the electoral dataset at the polling-booth level and the infrastructure dataset at the school level. Additional controls are added at the

\footnotetext{
${ }^{12}$ The original dataset contained a few extreme values that are probably entry errors. To clean the dataset, we excluded the polling booths in which the share of votes for Macri were two or more standard deviations above or below the mean of the school - approximately $2 \%$ of the sample (1\% per tail). Results, which are available upon request, remain identical when using the complete dataset, which suggests that the potential entry errors are randomly distributed with respect to the treatment.

${ }^{13}$ This dataset, although useful, is imperfect. Besides having missing values for the age of female voters, the registry does not correspond to the presidential election but the City local elections of Buenos Aires, as we could not get access to the registry for the presidential elections. In principle, these two datasets (presidential or local elections) should be almost identical: they correspond to the same district, and the allocation procedure to polling-booths is identical. However, there could be minimal differences explained by the fact that the local elections happened two months before the national elections. Therefore, some incoming voters just turned 18 in between elections and therefore were not in the local elections registry but were enrolled in the national one. We use this data to show that "treatment" is balanced, and, also to show that results hold with or without controlling for these variables.
} 


\section{Figure 2: Distribution of School Infrastructure Quality}

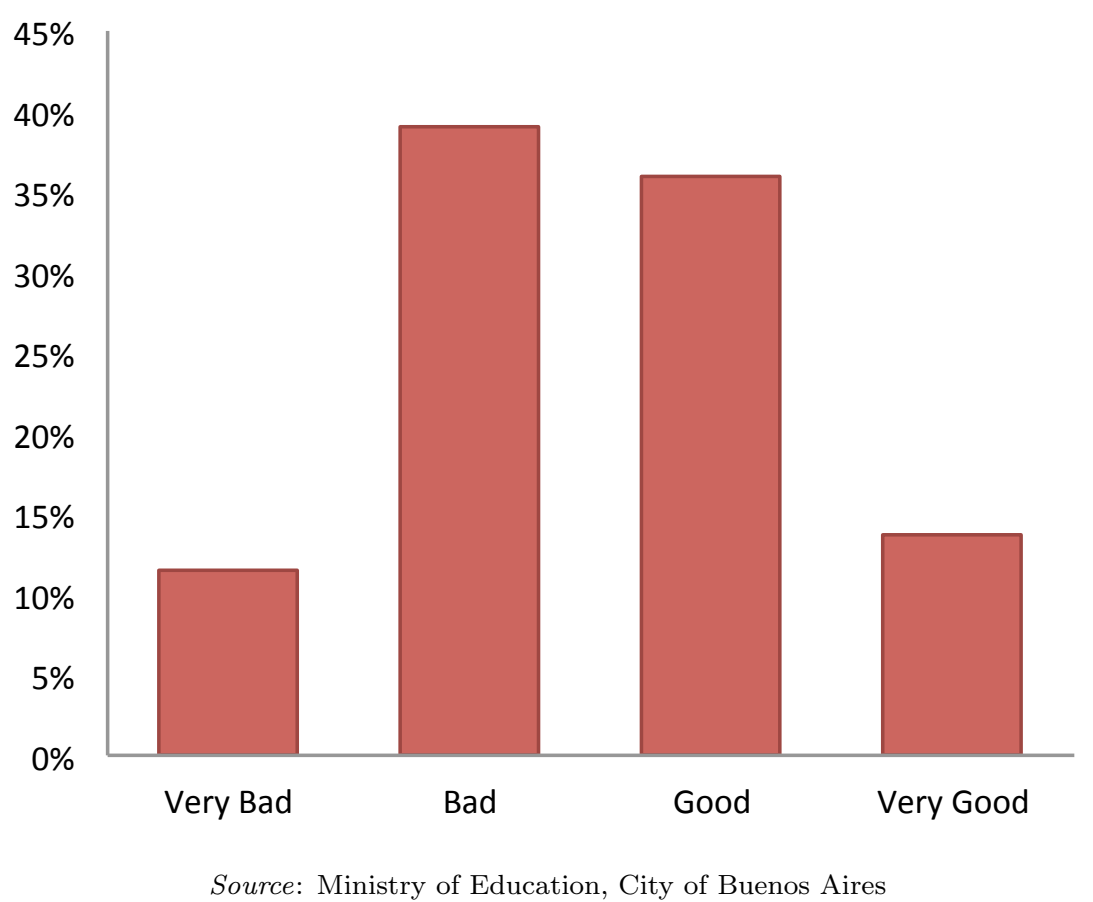

school level to enrich the analysis and perform robustness checks: as a measure of the average wealth of the area in which each school is located, we computed the average selling price of dwellings per block using online prices from one of the biggest real estate online marketplaces in Argentina (www.properati.com) corresponding to early 2016 (see Figure $5^{14}$ ). We also estimated the expected distance between each voter's household and the school at which they were assigned to vote. To do so - and given that individual information on citizens' addresses is not public - we computed the average distance in meters from each school to the centroid of the circuit (geographical center of the circuit). This measure assumes that, on average, a random individual in a certain electoral circuit will be farther away from the schools that are located farthest from the geographical center of the circuit. ${ }^{15}$

Finally, we use Census data from the last wave (2010) to obtain certain household characteristics. Individual level data is not available, but household-average data at the electoral circuit level allows us to compute the proportion of children in schooling age per household (defined as absolute children in school age divided by number of people in the electoral circuit), a relevant variable that could potentially mediate the effect of school public infras-

\footnotetext{
${ }^{14}$ Data at the circuit level was generously provided by Federico Bayle, to whom we are indebted.

${ }^{15}$ The matching of schools to polling booths was taken from an algorithm developed by Manuel Aristaran, to whom we are very grateful.
} 
tructure on voting decisions.

In order to avoid having too many electoral circuits without enough variability in the school's infrastructure quality, were performed the main analysis aggregating the four categories into two different levels: "Good" ("Very Good" or "Good") and "Bad" ("Very bad" or "Bad") schools. As Figure 3 shows, good and bad schools are evenly scattered along the map in most of the areas of the city. For robustness, we also present the results using the four different levels of quality.

\section{Figure 3: Distribution of "Good" and "Bad" schools}

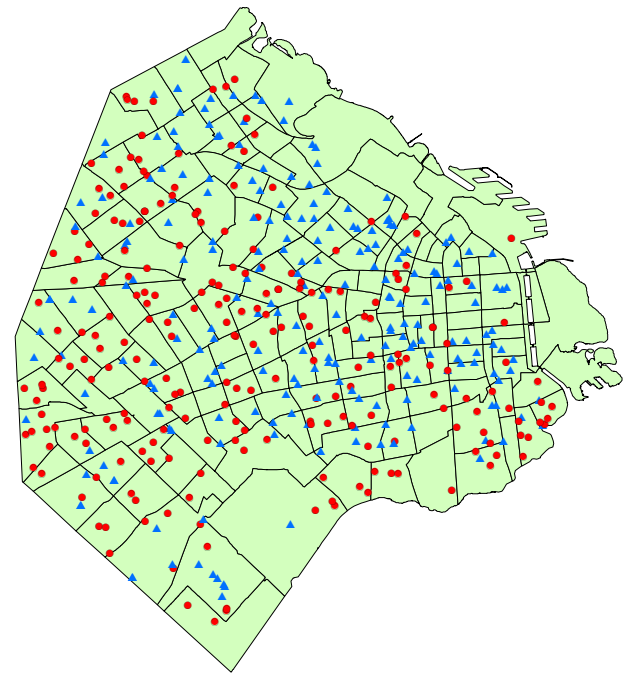

Note: Circles represent the "bad" schools, triangles represent the "good" schools

\section{Empirical Strategy}

To identify a causal effect, we exploit the random assignment of voters to schools within electoral circuits. This natural experiment allows us to compare voters who are similar in every dimension other than the type of school to which they were assigned for voting day. More specifically, we estimate the following models:

$$
\text { Macri }_{p t}=\alpha \text { BadQuality }_{s}+\eta_{c}+\gamma_{r}+\lambda X_{s}+\Lambda X_{p}+\epsilon_{p r}
$$




$$
\text { Macri }_{p t}=\alpha \text { BadQuality }_{s}+\beta \text { BadQuality }_{s} * \text { Upper Income }_{c}+\eta_{c}+\gamma_{r}+\lambda X_{s}+\Lambda X_{p}+\epsilon_{p r}
$$

$$
\text { Macri }_{p t}=\alpha \text { BadQuality }_{s}+\beta \text { BadQuality }_{s} * \text { LowDensityChildren }_{c}+\eta_{c}+\gamma_{r}+\lambda X_{s}+\Lambda X_{p}+\epsilon_{p r}
$$

$$
\begin{aligned}
& \text { Macri }_{p t}= \\
& =\alpha \text { BadQuality }_{s}+\beta \text { BadQuality }_{s} * \text { Upper Income }_{c}+ \\
& =\theta \text { BadQuality }_{s} * \text { LowDensityChildren }_{p}+ \\
& =\omega \text { BadQuality }_{s} \text { UpperIncome }_{c} * \text { Low DensityChildren }_{c}+ \\
& =+\eta_{c}+\gamma_{r}+\lambda X_{s}+\Lambda X_{p}+\epsilon_{p r}
\end{aligned}
$$

Where Macri $_{p t}$ represents the proportion of voters for Mauricio Macri out of the total positive votes (i.e., not blank) in the polling booth $p$ during round $r$; BadQuality is a dummy variable that has a value of one if the school $s$ has "bad" or "very bad" infrastructure and zero otherwise; $X_{s}$ is a set of controls at the school level; and $X_{p}$ is a set of controls at the polling-booth level (number of registered voters, proportion of male voters and average age). Controlling for number of voters assigned to the same ballot box is particularly important to rule out the possibility of a behavioural change induced by having larger or smaller queues if a voter was assigned to a polling booth with more or fewer voters.

UpperIncome $_{c}$ takes a value of one if the circuit $c$ in which the school is located is relatively rich (i.e., if the average price of dwellings in this area is above the sample median price of dwellings in the whole city) and zero otherwise; $\eta_{c}$ is an electoral circuit fixed effect; $\lambda_{r}$ is a round (or period) fixed effect.

LowDensityChildren $_{c}$ takes a value of one if the average proportion of children per household in the electoral circuit $c$, where the school is located, is below the median of the sample. Census individual data to know exactly how many children live in each household is not available. Instead, we use the average proportion of children per household in mandatory schooling age (up to fifteen years old) to determine if a school is located in a "low density of children" circuit.

Equations 2, 3 and 4 let us analyze the heterogeneity of the effects. In equation 2, $\alpha$ measures the effect of voting in a bad-quality school located in a relatively poorer electoral 
circuit, and $\alpha+\beta$ measures the effect for schools located in a relatively richer electoral circuit. In equation 3, $\alpha$ measures the effect of voting in a bad-quality school located in a "high density of children" circuit, and $\alpha+\beta$ measures the effect for schools located in a "low density of children" circuit.

In equation 4 , there are four parameters of interest measuring the effect of voting in a bad-quality school on voting preferences: $\alpha$ is the punishment effect among voters in schools located in lower-income circuits where the density of schooling-age children is high; $\alpha+\theta$ is the effect among voters in schools located in lower-income circuits where the density of school-age children is relatively low; $\alpha+\beta$ is the effect among voters in schools located in higher-income circuits where the density of schooling-age children is relatively high; and $\alpha+\beta+\theta+\omega$ is the effect among voters in schools located in higher-income circuits where the density of schooling-age children is relatively low.

Given that randomization is stratified at the circuit level (i.e., it is at the individual level, but conditional to the circuit of residence), the circuit fixed effect $\left(\eta_{c}\right)$ allows us to identify the causal effect of being assigned to vote in a "good" or "bad" school on voting behaviour. The school-level controls include dummies indicating the average selling price of the dwellings located on the same block as the school - with which we are able to rule out the possibility of a behavioural change induced by passing through a poor or unsafe street -, and dummies of the average expected distance between voters' households and each of the schools - which allows us to rule out the possibility of a behavioural change induced by having a longer or shorter commute and, finally, we control by the number of booths per school. Importantly, we also control for number of voters assigned to the same ballot box, which help us rule out the possibility of a behavioural change induced by having larger or smaller queues if a voter was assigned to a polling booth with more or fewer voters. Finally, we also control for the average age and average proportion of female voters at the booth level. We run all the regressions clustering the standard errors at the school level.

The main assumption of our identification strategy is that the alphabetical order of voters is not systematically correlated with the quality of infrastructure of each school within circuits. In other words, even if last names were correlated with unobserved voters' characteristics (e.g., wealthy families' last names starting with the letter A), we would be identifying a causal effect as long as these characteristics were not systematically correlated with school quality within circuit (e.g., voters with last names starting with the letter A voting always in the best schools of each circuit). Using age and gender at the ballot station level, and the number of electors per booth and the average housing price of the school's block, we show that, as expected, voters seem to be similar in good and bad infrastructure quality schools, at least in these observable characteristics: Table 3 shows that these variables are 
not significantly different between the different types of schools.

\section{$5 \quad$ Results and Interpretation}

Figures 6 and 7 show the kernel density estimation of the proportion of the total number of votes for Macri at the polling-booth level for different quality levels of school infrastructure. In Figure 7, quality types are collapsed into two aggregated categories (good and bad). Both figures suggest a positive correlation between voting for Macri and voting in a good-quality school. Figure 6 suggests that this correlation might even be monotonic: the distribution of votes tends to be further right-skewed as the quality of the school in which polling booths are located improves. In the most extreme comparison ("very good" versus "very bad"), the slant is very evident.

These graphs, although suggestive, do not take into account the potential biases that can arise when comparing the voting behaviour of citizens living in different electoral circuits. In Table 4, we formally analyze this relationship by showing the estimation of equations 1,2 and 3 .

The main results are presented in two sets of columns: the difference between set $(\mathrm{A})$ and (B) is the definition of the dependent variable. Set (A) defines the outcome as the number of votes for Macri divided by the total number of valid votes. Set (B) defines the outcome as the number of votes for the Cambiemos Alliance divided by the total number of valid votes. This difference is only relevant for the primary elections (PASO): in the first and second round of the general elections, the number of votes for the coalition are identical after the primary. Models (1), (2) and (3) show the results of regressions 1, 2 and 3, respectively.

As expected, the results in Table 4 show that there is significant electoral punishment of Macri in the schools categorized as having "bad" infrastructural quality (Tables 8 and 9 in the Appendix show the results with different set of controls and using different definitions of the dependent variable). Interestingly enough, the punishment is fully concentrated among the poorest circuits of the city and those with a higher density of children per household. The proportion of votes for Macri in a lower-income area is between 0.49 p.p. and 0.53 lower in a "bad quality" school than in a "good quality" one. The magnitude of the effect among the lower income areas is considerable, especially when taking into account the fact that the "treatment" is rather mild: no explicit information was provided to voters other than whatever information they could extract from being exposed to different types of schools.

Different stories could be consistent with relatively bigger or smaller punishment in richer versus poorer areas. As Dias and Ferraz (2017) point out, although they do not find evidence consistent with this hypothesis, more-educated families may place a higher value on 
the quality of public education, including the facilities, and would, therefore, punish poor conditions more.

On the other hand, less-wealthy families may be more likely to use public schools and should, therefore, be more concerned about the quality of public education than richer families that can access private schools. It may even be possible that a rich family that does not use public schools values a government that minimizes expenditures on public schools and uses the public funds for other types of public assets (parks, recreation, culture, for instance). If so, richer families would reward the mayor for the low quality of public schools, or at least would not punish him. ${ }^{16}$

Results seem to be more consistent with this second interpretation. According to the last official data from the Ministry of Education of the City of Buenos Aires in 2015, approximately $50 \%$ of the population with children going to primary or secondary school chooses private over public institutions, and the choice of a public school drastically decreases as the household income increases. As an example, a family with school-aged children in a household in the $25^{\text {th }}$ percentile is 30 p.p. more likely to use public institutions than a household in the $75^{\text {th }}$ percentile, even within the same neighborhood.

A plausible interpretation of these results is that individuals who are potentially more likely to use public infrastructure (in this case, schools) have a stronger preference for politicians who improve the quality of public goods. The expected result in this case would be to observe significant electoral punishment from the poor and no electoral effect from the rich.

Consistent with this hypothesis (i.e., people more interested in high-quality public education react the most), we also show a larger effect in demographic groups with presumably stronger interest in the quality of schools' infrastructure, as they are more likely to have children in schooling age should. Electoral punishment goes from 0.52 to 0.60 p.p. in circuits with higher density of children per household, as Columns (3) of Table 4 show. ${ }^{17}$

In Table 5 we show the results of Equation 4, which let us compare the effect by different type of circuits: lower-income/higher-income and with low/high density of schooling-age children. As expected, the highest effect is concentrated among schools located in lowerincome/higher density of children circuits. The point estimates become even more significant than the average effect and the magnitude becomes large: between 0.58 and 0.67 , depending on the definition used for the dependent variable. Interestingly, the effect is maximized among voters for whom public education is particularly important but also who had more

\footnotetext{
${ }^{16}$ For a discussion about voting and the demand for public services when there are private alternatives, see Epple and Romano (1996) and Stiglitz (1974).

${ }^{17}$ In Tables 10 and 11, we also show the results using the four categories of infrastructure quality. As expected, the punishment increases as the quality of school worsens. These results must be taken cautiously because there is not enough within-circuit variation: only a few circuits contain the four types of schools.
} 
chances to be aware of the state of public school infrastructure because they are more likely to use public schools.

This pattern suggests that the effect is not driven by an informational update, given that citizens that were most likely to be already exposed to the quality of schools are those that drive the main effect. Consistent with this hypothesis, we show in table 6 that the interaction effect of expected average distance to schools and the main effect is zero. This means that citizens that are on average farther away from the schools were they vote (and thus, are less likely to have already passed by that school) are not more likely to punish the incumbent when assigned to vote in a poor-quality school than people living relatively closer by.

Finally, in Table 7 we test whether there is an effect on turnout or the proportion of valid votes and find no effect in either of these variables. Citizens' behaviour does not seem to be affected ex-ante: people are affected only when they are physically exposed to the relatively worse (or better) quality of the schools where they cast their votes. The lack of effect on the proportion of valid votes suggests that there were no punishment or reward to the political establishment in general, only to the mayor.

These results are consistent with the theories of frictions and mental gaps (Handel and Schwartzstein (2018)), according to which even readily available information is not automatically translated into knowledge. Making public infrastructure salient at the polling station exactly at the moment of voting seemed to be an effective way of catching voter's attention and making them incorporate useful information to assess the performance of the government. These results highlight how the forms and the context in which information is presented is crucial: more-salient information provided at the right moment could probably carry a higher weight in our decision-making process (DellaVigna (2009)). Even for people that were more likely to be exposed to public school infrastructure in the first place (households with children living in lower-income areas, or living relatively closer by the schools where they vote), showing bad quality infrastructure at the right moment seemed to have had a disproportionate effect. Results also support the idea that more visible government actions could be more influential than equally important but less noticeable policies (Mani and Mukand (2007), Harding and Stasavage (2013), Robinson and Torvik (2005)).

\section{Conclusions}

This paper shows how people's voting behaviour is affected by contextual factors. In particular, it examines how citizens extract novel information from the physical settings of the polling place to signal the quality of public services - in this case, the infrastructural quality of public schools - and punish or reward the incumbents. We performed the analysis 
in a particularly suitable context: the 2015 presidential election of Argentina, when one of the main candidates was the mayor of Buenos Aires, who had been in charge of the infrastructural quality of public schools during the previous eight years. To identify a causal effect, we took advantage of a natural experiment in which voters are randomly assigned to polling booths in schools with different levels of infrastructural quality.

We show that the citizens of Buenos Aires, who were assigned to cast their votes in public schools with relatively more deficient infrastructure punished the mayor by decreasing his vote share by 0.18 p.p. we also show that the effect increased among the groups who presumably had stronger preferences for public education: voters in lower-income areas and voters in households with a potentially higher number of children in schooling age.

The magnitude of the effect is relatively in line with that found in other papers. Chong et al. (2014), for example, estimated the effect of distributing flyers with the results of mayors' corruption audits in Mexico and found punishment to the incumbent of 0.43 p.p. among treated voters. Dias and Ferraz (2017) found a punishment/reward effect of -1.6/+2 p.p. after providing voters with information about the quality of education in Brazil. Although they found a larger effect, the treatment was also more "intense", as it referred to a largescale accountability system whereby the Federal Government released the school-level results of educational quality.

Taken together, the results of this paper suggest that voters extract useful information from seemingly unimportant places. Moreover, this paper shows that citizens may obtain valuable information about politicians by directly observing the results of their implemented public policies (i.e., without the need for massive and explicit diffusion of information about politicians' performance or corruption). Overall, this paper emphasises the relevance of context in decision-making: the moment and salience of information matters in affecting voter's decisions. The forms and context in which information is provided may matter as much as its content.

\section{References}

Alberto Alesina, Dorian Carloni, and Giampaolo Lecce. The electoral consequences of large fiscal adjustments. In Fiscal policy after the financial crisis, pages 531-570. University of Chicago Press, 2012.

Scott Ashworth. Electoral accountability: recent theoretical and empirical work. Annual Review of Political Science, 15:183-201, 2012. 
Abhijit Banerjee, Selvan Kumar, Rohini Pande, and Felix Su. Do informed voters make better choices? experimental evidence from urban india. Unpublished manuscript, 2011.

Robert J Barro. The control of politicians: an economic model. Public Choice, 14(1):19-42, 1973.

Jonah Berger, Marc Meredith, and S Christian Wheeler. Contextual priming: Where people vote affects how they vote. Proceedings of the National Academy of Sciences, 105(26): 8846-8849, 2008.

Besley. Principled agents. 2007.

Jens Blom-Hansen, Jørgen Elklit, Søren Serritzlew, and Louise Riis Villadsen. Ballot position and election results: Evidence from a natural experiment. Electoral Studies, 44:172-183, 2016.

Adi Brender. The effect of fiscal performance on local government election results in israel: 1989-1998. Journal of Public Economics, 87(9-10):2187-2205, 2003.

Adi Brender and Allan Drazen. How do budget deficits and economic growth affect reelection prospects? evidence from a large panel of countries. American Economic Review, 98(5): 2203-20, 2008.

Lorenzo Casaburi and Ugo Troiano. Ghost-house busters: The electoral response to a large anti-tax evasion program. The Quarterly Journal of Economics, 131(1):273-314, 2015.

Agustín Casas, Guillermo Díaz, and Andre Trindade. Who monitors the monitor? effect of party observers on electoral outcomes. Journal of Public Economics, 145:136-149, 2017.

Raj Chetty, Adam Looney, and Kory Kroft. Salience and taxation: Theory and evidence. American Economic Review, 99(4):1145-77, 2009.

Alberto Chong, Ana L De La O, Dean Karlan, and Leonard Wantchekon. Does corruption information inspire the fight or quash the hope? a field experiment in mexico on voter turnout, choice, and party identification. The Journal of Politics, 77(1):55-71, 2014.

Stefano DellaVigna. Psychology and economics: Evidence from the field. Journal of Economic literature, 47(2):315-72, 2009.

Stefano DellaVigna and Joshua M Pollet. Investor inattention and friday earnings announcements. The Journal of Finance, 64(2):709-749, 2009. 
Marina Dias and Claudio Ferraz. Voting for quality? the impact of school quality information on electoral outcomes. manuscript, 2017.

Francesco Drago, Tommaso Nannicini, and Francesco Sobbrio. Meet the press: How voters and politicians respond to newspaper entry and exit. American Economic Journal: Applied Economics, 6(3):159-88, 2014.

Francesco Drago, Roberto Galbiati, and Francesco Sobbrio. Voters' response to public policies: Evidence from a natural experiment. Technical report, CESifo Working Paper, 2017.

John Duggan and César Martinelli. The political economy of dynamic elections: Accountability, commitment, and responsiveness. Journal of Economic Literature, 55(3):916-84, 2017.

Dennis Epple and Richard E Romano. Ends against the middle: Determining public service provision when there are private alternatives. Journal of Public Economics, 62(3):297-325, 1996.

John Ferejohn. Incumbent performance and electoral control. Public Choice, 50(1-3):5-25, 1986.

Claudio Ferraz and Frederico Finan. Exposing corrupt politicians: the effects of brazil's publicly released audits on electoral outcomes. The Quarterly Journal of Economics, 123 (2):703-745, 2008.

Amy Finkelstein. E-ztax: Tax salience and tax rates. The Quarterly Journal of Economics, 124(3):969-1010, 2009.

Xavier Gabaix. Behavioral inattention. Technical report, National Bureau of Economic Research, 2017.

Benjamin Handel and Joshua Schwartzstein. Frictions or mental gaps: What's behind the information we (don't) use and when do we care? Journal of Economic Perspectives, 32 (1):155-78, 2018.

Robin Harding and David Stasavage. What democracy does (and doesnt do) for basic services: School fees, school inputs, and african elections. The Journal of Politics, 76(1):229-245, 2013.

Andrew Healy, Neil Malhotra, et al. Random events, economic losses, and retrospective voting: Implications for democratic competence. Quarterly Journal of Political Science, 5 (2):193-208, 2010. 
Tanjim Hossain and John Morgan. ... plus shipping and handling: Revenue (non) equivalence in field experiments on ebay. Advances in Economic Analysis \& Policy, 5(2), 2006.

Emir Kamenica. Behavioral economics and psychology of incentives. Annual Review of Economics, 4(1):427-452, 2012.

Jonathan GS Koppell and Jennifer A Steen. The effects of ballot position on election outcomes. The Journal of Politics, 66(1):267-281, 2004.

Horacio A Larreguy, John Marshall, and James M Snyder Jr. Publicizing malfeasance: When media facilitates electoral accountability in mexico. Cambridge, Harvard University, manuscript, 2015.

Anandi Mani and Sharun Mukand. Democracy, visibility and public good provision. Journal of Development Economics, 83(2):506-529, 2007.

Kamil Marcinkiewicz. Electoral contexts that assist voter coordination: Ballot position effects in poland. Electoral Studies, 33:322-334, 2014.

Joanne M Miller and Jon A Krosnick. The impact of candidate name order on election outcomes. Public Opinion Quarterly, pages 291-330, 1998.

Tommaso Nannicini, Andrea Stella, Guido Tabellini, and Ugo Troiano. Social capital and political accountability. American Economic Journal: Economic Policy, 5(2):222-50, 2013.

Rohini Pande. Can informed voters enforce better governance? experiments in low-income democracies. Annual Review of Economics, 3(1):215-237, 2011.

Timothy J Power and James C Garand. Determinants of invalid voting in latin america. Electoral Studies, 26(2):432-444, 2007.

Axel Rivas and Daniela Dborkin. ¿ qué cambió en el financiamiento educativo en argentina? CIPPEC, 2018.

James A Robinson and Ragnar Torvik. White elephants. Journal of Public Economics, 89 (2-3):197-210, 2005.

Kelly Shue and Erzo FP Luttmer. Who misvotes? the effect of differential cognition costs on election outcomes. American Economic Journal: Economic Policy, 1(1):229-57, 2009.

Joseph E Stiglitz. The demand for education in public and private school systems. Journal of Public Economics, 3(4):349-385, 1974. 


\section{$7 \quad$ Tables and Figures}

Table 1: Electoral Descriptive Statistics (by polling booth)

\begin{tabular}{|c|c|c|c|c|c|}
\hline & Electors & $\begin{array}{c}\text { Turnout } \\
\text { (percentage) }\end{array}$ & $\begin{array}{c}\text { Positive votes } \\
\text { ratio } \\
\text { (percentage) }\end{array}$ & $\begin{array}{c}\text { Votes for } \\
\text { Macri } \\
\text { (percentage) }\end{array}$ & $\begin{array}{l}\text { No. of Polling } \\
\text { Booths }\end{array}$ \\
\hline PASO & 346 & $\begin{array}{c}73.1 \\
(2.95)\end{array}$ & $\begin{array}{c}98.1 \\
(6.1)\end{array}$ & $\begin{array}{c}40 \\
(1.6)\end{array}$ & $4,4,331$ \\
\hline $1^{\text {st }}$ Round & 346 & $\begin{array}{c}78.2 \\
(2.99)\end{array}$ & $\begin{array}{r}98.8 \\
(4.7)\end{array}$ & $\begin{array}{l}48.5 \\
(1.7)\end{array}$ & 4,331 \\
\hline $2^{\text {nd }}$ Round & 346 & $\begin{array}{c}77.8 \\
(2.99)\end{array}$ & $\begin{array}{l}97.8 \\
(4.2)\end{array}$ & $\begin{array}{c}63.1 \\
(1.9)\end{array}$ & 4,331 \\
\hline Pooled Elections & 346 & $\begin{array}{c}76.4 \\
(2.99)\end{array}$ & $\begin{array}{l}98.2 \\
(5.5)\end{array}$ & $\begin{array}{l}50.5 \\
(1.8)\end{array}$ & 4,331 \\
\hline
\end{tabular}

Definitions: Electors: total number of registered voters. Turnout: total number of votes for any candidate plus blank votes divided by the total number of registered voters. Positive votes ratio: total number of votes for any valid candidate divided by the total number of votes. Votes for Macri: number of votes cast for the candidate Mauricio Macri divided by the total number of valid votes. No. of Polling Booths: sum of all the polling booths in the sample. PASO: primary elections, $1^{\text {st }}$ Round: first round of the general election, $2^{\text {nd }}$ Round: runoff round of the general election. Mean values at the "precinct" (school) level in first rows, standard deviations in parentheses.

Table 2: Electoral Descriptive Statistics (by schools level of infrastructure)

\begin{tabular}{|c|c|c|c|c|}
\hline & Very Bad & $\mathrm{Bad}$ & Good & Very Good \\
\hline No. of "precincts (schools) & 53 & 180 & 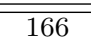 & 63 \\
\hline Turnout (percentage) & $\begin{array}{l}76.8 \\
(7.3)\end{array}$ & $\begin{array}{c}77 \\
(6.2)\end{array}$ & $\begin{array}{c}76.8 \\
(7.1)\end{array}$ & $\begin{array}{c}75 \\
(6.9)\end{array}$ \\
\hline Positive votes ratio (percentage) & $\begin{array}{c}98.2 \\
(3)\end{array}$ & $\begin{array}{l}98.1 \\
(2.0)\end{array}$ & $\begin{array}{l}98.2 \\
(1.4)\end{array}$ & $\begin{array}{l}98.2 \\
(1.2)\end{array}$ \\
\hline Votes for Macri (percentage) & $\begin{array}{c}45.7 \\
(12.9)\end{array}$ & $\begin{array}{c}49.2 \\
(13.5)\end{array}$ & $\begin{array}{c}51.6 \\
(14.8)\end{array}$ & $\begin{array}{c}53.7 \\
(13.8)\end{array}$ \\
\hline Number of Electores per polling station & $\begin{array}{c}346.4 \\
(3.1)\end{array}$ & $\begin{array}{c}346.5 \\
(3.0)\end{array}$ & $\begin{array}{c}346.9 \\
(3.0)\end{array}$ & $\begin{array}{l}346.8 \\
(2.8)\end{array}$ \\
\hline
\end{tabular}

Definitions: Turnout: total number of votes for any candidate plus blank votes divided by the total number of registered voters. Positive votes ratio: total number of votes for any valid candidate divided by the total number of votes. Votes for Macri: total number of votes cast for the candidate Mauricio Macri divided by the total number of valid votes. "Very Bad", "Bad", "Good", "Very Good" are the four different categories used to measure the infrastructure quality of schools. 
Table 3: Balance test

\begin{tabular}{|c|c|c|c|c|}
\hline \multicolumn{5}{|c|}{ Equation 1} \\
\hline & No. Electors & Housing Prices & Age & Male \\
\hline Bad Quality & $\begin{array}{c}-0.09 \\
(0.07) \\
{[-0.03 \sigma]}\end{array}$ & $\begin{array}{c}49 \\
(70) \\
{[0.07 \sigma]}\end{array}$ & $\begin{array}{c}0.09 \\
(0.065) \\
{[0.002 \sigma]}\end{array}$ & $\begin{array}{c}0.0007 \\
(0.012) \\
{[0.0014 \sigma]}\end{array}$ \\
\hline Observations & 12.958 & 12.958 & 531,272 & $1,100,374$ \\
\hline R-Squared & 0.03 & 0.03 & 0.03 & 0.03 \\
\hline
\end{tabular}

Standard Errors clustered at the school level in parentheses ${ }^{* * *} \mathrm{p}<0.01,{ }^{* *} \mathrm{p}<0.05,{ }^{*} \mathrm{p}<0.1$

Regressions include electoral circuit fixed effects.

(A): Age is defined in years and correspond only to male voters.

(B): Male: takes a one if the voter is a male and a 0 otherwise

Figure 4: Electoral Results at the National Level (percentage)
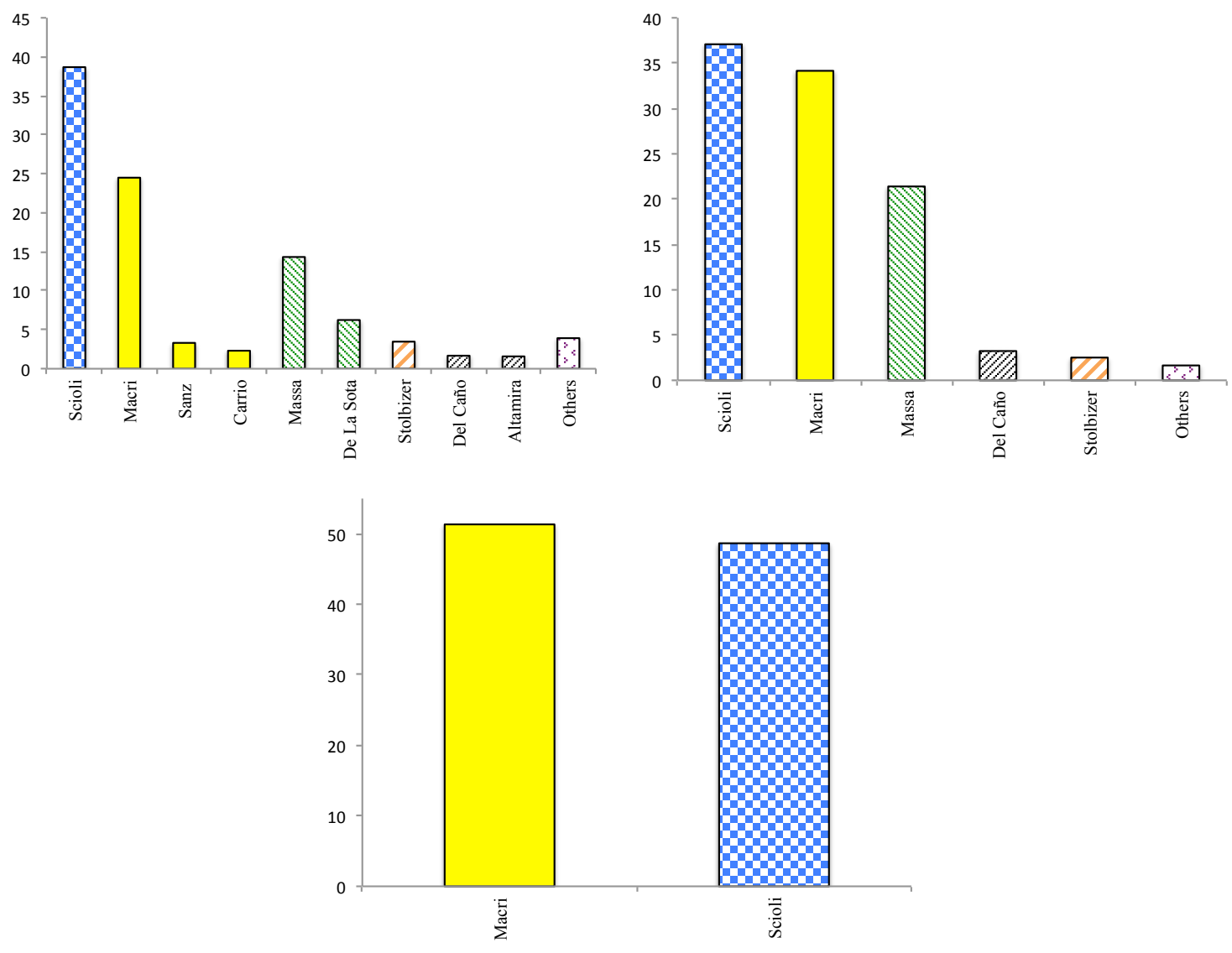

Source: Camara Nacional Electoral

Note: The $1^{\text {st }}$ figure corresponds to the results of the PASO election; the $2^{\text {nd }}$ and $3^{\text {rd }}$ figures correspond to the $1^{\text {st }}$ and $2^{\text {nd }}$ rounds of the general election. Bars are grouped by party: Scioli (FPV), Macri, Sanz, Carrio (Cambiemos), Massa and De la Sota

(UNA), Stolbizer (Progresistas), Altamira and Del Caño (FIT). The description of each party/coalition can be found in the Appendix. 
Figure 5: Average housing selling prices by circuit in US\$

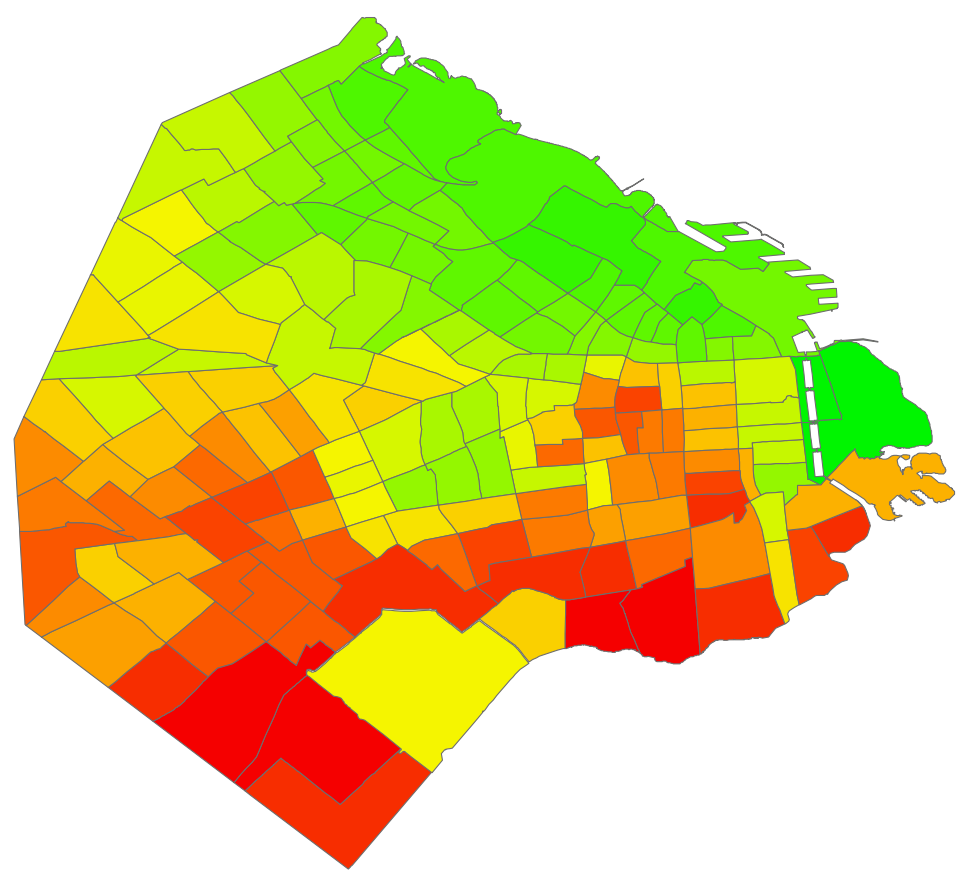

Source: www.properati.com 
Figure 6: Kernel Density Estimation: Votes for Macri by School Quality Level

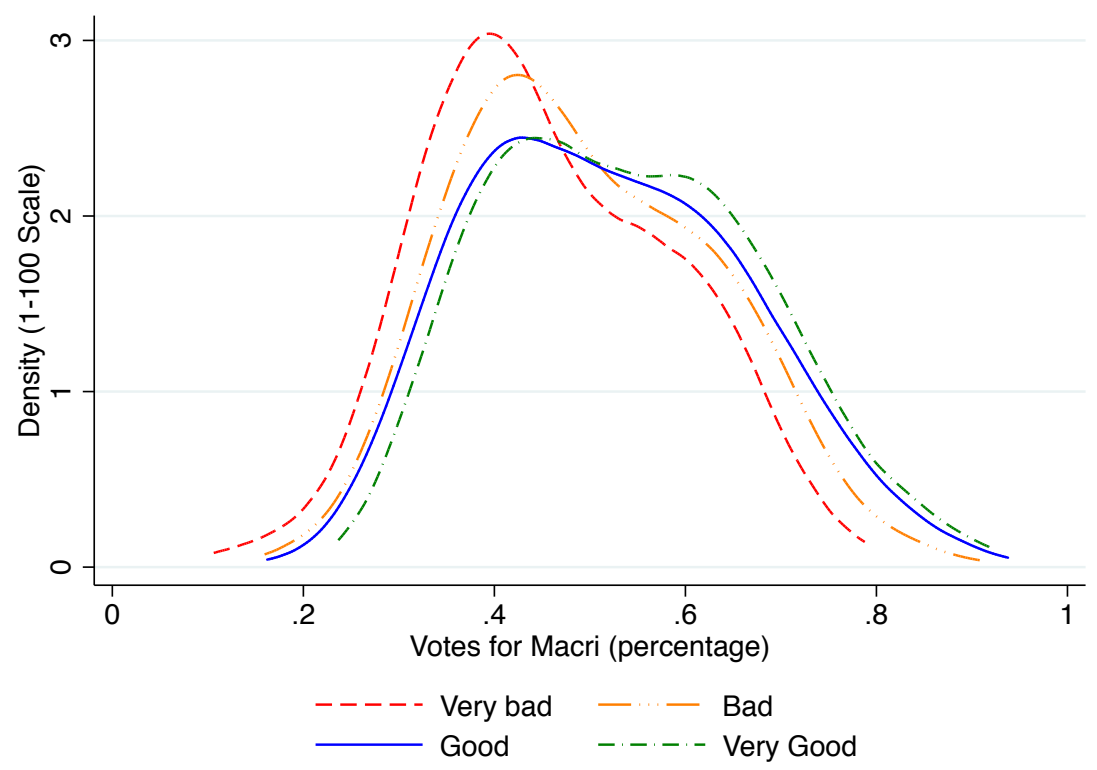

Note: Bandwidth:0.05. Votes at the polling booth level, three rounds of elections pooled.

Figure 7: Kernel Density Estimation: Votes for Macri by School Quality Level (aggregated)

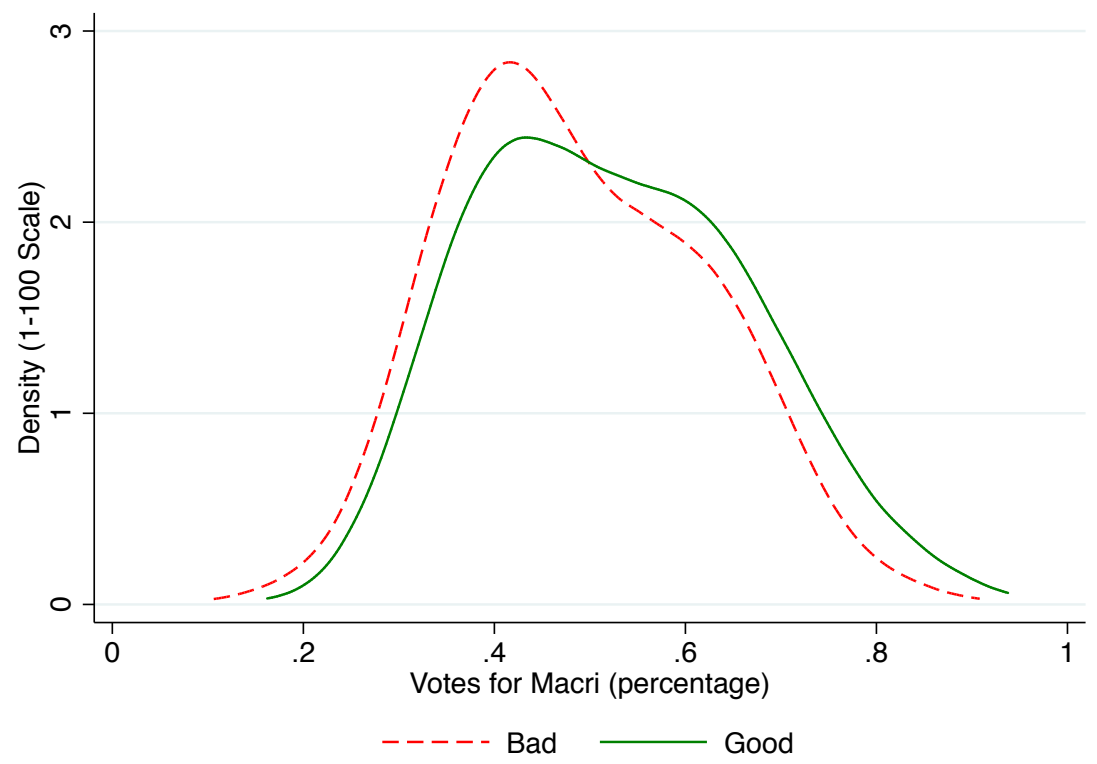

Note: Bandwidth:0.05. Votes at the polling booth level, three rounds of elections pooled. 
Table 4: Effect of School Quality on Voting for Macri (percentage)

\begin{tabular}{|c|c|c|c|c|c|c|}
\hline \multicolumn{7}{|c|}{ Equations 1 and 2} \\
\hline & \multicolumn{3}{|c|}{$(\mathrm{A})$} & \multicolumn{3}{|c|}{ (B) } \\
\hline & (1) & $(2)$ & (3) & $(1)$ & $(2)$ & $(3)$ \\
\hline Bad Quality & $\begin{array}{c}-0.21^{*} \\
(0.11)\end{array}$ & $\begin{array}{c}-0.49^{* * *} \\
(0.16)\end{array}$ & $\begin{array}{c}-0.52^{* *} \\
(0.17)\end{array}$ & $\begin{array}{l}-0.22^{*} \\
(0.11)\end{array}$ & $\begin{array}{c}-0.53^{* * *} \\
(0.17)\end{array}$ & $\begin{array}{c}-0.60^{* * *} \\
(0.18)\end{array}$ \\
\hline Bad Quality * Upper Income Circuit & & $\begin{array}{c}0.53^{* * *} \\
(0.22)\end{array}$ & & & $\begin{array}{c}0.54^{* * *} \\
(0.17)\end{array}$ & \\
\hline Total Effect (Upper Income Circuits) & & $\begin{array}{c}0.03 \\
(0.15)\end{array}$ & & & $\begin{array}{c}0.05 \\
(0.15)\end{array}$ & \\
\hline Bad Quality * Low Den. of Child. & & & $\begin{array}{c}0.55^{* * *} \\
(0.21)\end{array}$ & & & $\begin{array}{c}0.66^{* * *} \\
(0.23)\end{array}$ \\
\hline Total Effect (LDC) & & & $\begin{array}{l}0.024 \\
(0.13)\end{array}$ & & & $\begin{array}{c}0.06 \\
(0.14)\end{array}$ \\
\hline Obs. & 12,626 & 12,626 & 12,626 & 12,626 & 12,626 & 12,626 \\
\hline R-Squared & 0.91 & 0.91 & 0.92 & 0.92 & 0.92 & 0.92 \\
\hline
\end{tabular}

Standard Errors clustered at the school level in parentheses

$* * * \mathrm{p}<0.01, * * \mathrm{p}<0.05,{ }^{*} \mathrm{p}<0.1$

Regressions include electoral circuit fixed effects, round fixed effect, school and polling station controls as described in Section 3 .

(A): Definition of the dependent variable: total number of votes for Macri divided by the total number of valid votes (PASO election, first round of the general election and runoff of the general election).

(B): Definition of the dependent variable: total number of votes for Macri divided by the total number of valid votes (first round of the general election and runoff of the general election). Total number of votes for Macri or any other candidate in the Cambiemos Alliance divided by the total number of valid votes (PASO election).

"Upper Income Circuit": 1 if the average housing price in the circuit is above the median of the city, 0 otherwise. "Low Density of Children": 1 if the average proportion of households with children between 0 and 15 is below the median of the city, 0 otherwise. 
Table 5: Effect of School Quality on Voting for Macri (percentage)

\begin{tabular}{|c|c|c|c|c|}
\hline & \multicolumn{3}{|c|}{ Equations 1 and 3} & \\
\hline & \multicolumn{2}{|c|}{$(\mathrm{A})$} & \multicolumn{2}{|c|}{ (B) } \\
\hline & $(1)$ & $(2)$ & (1) & $(2)$ \\
\hline Bad Quality (BQ) & $-0.21^{*}$ & $-0.58^{* * *}$ & $-0.22^{*}$ & $-0.67^{* * *}$ \\
\hline BQ ${ }^{*}$ Upper Income Circuit (UIC) & & $\begin{array}{c}0.25 \\
(0.40)\end{array}$ & & $\begin{array}{c}0.33 \\
(0.41)\end{array}$ \\
\hline BQ * Low Density of Children (LDC) & & $\begin{array}{c}0.54 * * \\
(0.26)\end{array}$ & & $\begin{array}{l}0.50^{*} \\
(0.36)\end{array}$ \\
\hline $\mathrm{BQ} * \mathrm{UIC} * \mathrm{LDC}$ & & $\begin{array}{c}-0.5 \\
(0.36)\end{array}$ & & $\begin{array}{c}0.03 \\
(0.54)\end{array}$ \\
\hline Effect on Lower-Income + HDC & & $-0.58^{* * *}$ & & $-0.67 * * *$ \\
\hline Effect on Lower-Income + LDC & & -0.27 & & -0.17 \\
\hline Effect on Higher Income + LDC & & -0.32 & & -0.34 \\
\hline Effect on Higher Income + HDC & & 0.11 & & 0.12 \\
\hline Obs. & 12,626 & 12,626 & 12,626 & 12,626 \\
\hline R-Squared & 0.83 & 0.83 & 0.86 & 0.86 \\
\hline
\end{tabular}

Standard Errors clustered at the school level in parentheses

*** $\mathrm{p}<0.01,{ }^{* *} \mathrm{p}<0.05,{ }^{*} \mathrm{p}<0.1$

Regressions include electoral circuit fixed effects, round fixed effect and the time-varying school controls described in Section 3. Regressions include electoral circuit fixed effects, round fixed effect, school and polling station controls as described in Section 3 .

(A): Definition of the dependent variable: total number of votes for Macri divided by the total number of valid votes (PASO election, first round of the general election and runoff of the general election).

(B): Definition of the dependent variable: total number of votes for Macri divided by the total number of valid votes (first round of the general election and runoff of the general election). Total number of votes for Macri or any other candidate in the Cambiemos Alliance divided by the total number of valid votes (PASO election).

"Upper Income Circuit": 1 if the average housing price in the circuit is above the median of the city, 0 otherwise. "Low Density of Children": 1 if the average proportion of households with children between 0 and 15 is below the median of the city, 0 otherwise.

\section{Table 6: Effect of School Quality on Voting for Macri (percentage)}

\begin{tabular}{|c|c|c|c|c|}
\hline & \multicolumn{3}{|c|}{ Equations 1 and 3} & \\
\hline & \multicolumn{2}{|c|}{$(\mathrm{A})$} & \multicolumn{2}{|c|}{ (B) } \\
\hline & (1) & $(2)$ & (1) & $(2)$ \\
\hline Bad Quality (BQ) & $-0.21^{*}$ & $-0.23^{*}$ & $-0.27^{* *}$ & $-0.67^{* * *}$ \\
\hline & $(0.11)$ & $(0.12)$ & $(0.11)$ & $(0.12)$ \\
\hline BQ * Distance (centered) & & $\begin{array}{c}0 \\
(0.003)\end{array}$ & & $\begin{array}{c}0 \\
(0.004)\end{array}$ \\
\hline Obs. & 12,626 & 12,626 & 12,626 & 12,626 \\
\hline R-Squared & 0.83 & 0.83 & 0.86 & 0.86 \\
\hline
\end{tabular}

Standard Errors clustered at the school level in parentheses

*** $\mathrm{p}<0.01, * * \mathrm{p}<0.05,{ }^{*} \mathrm{p}<0.1$

Regressions include electoral circuit fixed effects, round fixed effect and the time-varying school controls described in Section 3. Regressions include electoral circuit fixed effects, round fixed effect, school and polling station controls as described in Section 3.

(A): Definition of the dependent variable: total number of votes for Macri divided by the total number of valid votes (PASO election, first round of the general election and runoff of the general election).

(B): Definition of the dependent variable: total number of votes for Macri divided by the total number of valid votes (first round of the general election and runoff of the general election). Total number of votes for Macri or any other candidate in the Cambiemos Alliance divided by the total number of valid votes (PASO election).

"Distance" in meters is centered (i.e, demeaned) 
Table 7: Effect of School Quality on Turnout and Valid Votes (percentage)

\begin{tabular}{|c|c|c|c|c|c|c|}
\hline & \multicolumn{4}{|c|}{ Equations 1 and 2} & & \\
\hline & \multicolumn{2}{|c|}{ Full Controls } & \multicolumn{2}{|c|}{ School Controls } & \multicolumn{2}{|c|}{ Round and Circuit FE } \\
\hline & Turnout & Valid & Turnout & Valid & Turnout & Valid \\
\hline Bad Quality & $\begin{array}{r}-0.007 \\
(0.09)\end{array}$ & $\begin{array}{l}0.005 \\
(0.02)\end{array}$ & $\begin{array}{c}-0.009 \\
(0.09)\end{array}$ & $\begin{array}{l}0.004 \\
(0.03)\end{array}$ & $\begin{array}{c}0.02 \\
(0.09)\end{array}$ & $\begin{array}{c}0.02 \\
(0.03)\end{array}$ \\
\hline $\begin{array}{c}\text { Obs. } \\
\text { R-Squared }\end{array}$ & $\begin{array}{c}12,652 \\
0.83\end{array}$ & $\begin{array}{c}12,652 \\
0.83\end{array}$ & $\begin{array}{c}12,652 \\
0.83\end{array}$ & $\begin{array}{c}12,652 \\
0.83\end{array}$ & $\begin{array}{c}12,652 \\
0.86\end{array}$ & $\begin{array}{c}12,652 \\
0.86\end{array}$ \\
\hline
\end{tabular}

Standard Errors clustered at the school level in parentheses

*** $\mathrm{p}<0.01,{ }^{* *} \mathrm{p}<0.05,{ }^{*} \mathrm{p}<0.1$

Set of control per column: "Full controls" includes electoral circuit fixed effects, round fixed effect, school and polling station controls as described in Section 3. "School Controls" includes electoral circuit fixed effects, round fixed effect, and school controls as described in Section 3. "Round and Circuit FE" includes electoral circuit fixed effects and round fixed effect.

Definition of the dependent variables: "Turnout" is the number of votes (valid or not) divided by the number of electors in a polling station. "Valid" is the number of valid votes divided by the number of votes in a polling station.

\section{Appendix}

\subsection{Main Parties}

Formally, eleven parties competed in the PASO (compulsory primary elections), although only five obtained at least $1.5 \%$ of the votes and therefore could compete in the general election:

Frente para la Victoria (FPV): Led by the incumbent President Cristina Fernandez de Kirchner. The party was in charge of the federal government from 2003 to 2015. It is the most recent faction of the Peronist party. The party had only one candidate in the PASO elections: Daniel Scioli.

Cambiemos: A coalition led by Mauricio Macri, who was the Mayor of the City of Buenos Aires from 2007 to 2015. Typically associated with the modern, center-right political trend. The party had three candidates running against each other in the PASO elections: Mauricio Macri - who obtained the vast majority of the votes within the coalition - Ernesto Sanz and Elisa Carrió.

Unidos por una Nueva Alternativa (UNA): A coalition formed by the biggest faction of the Peronism not aligned with the FPV. Normally associated with a conservative centerright ideology. Two candidates ran for this partys nomination in the PASO elections: Sergio Massa and José de la Sota.

Progresistas: A progressive coalition, associated with the center-left. The party had only one candidate for the PASO elections: Margarita Stolbizer.

Compromiso Federal: A conservative/centrist faction of the Peronist party, but with a very specific regional origin in the province of San Luis, where the party has continuously 
governed since 1983. Alberto Rodriguez Saa was the partys presented only candidate for the PASO elections.

Frente de Izquierda y de los Trabajadores (FIT): A left wing coalition. The party presented two candidates for the PASO elections: Nicolas del Caño and Jorge Altamira. 


\subsection{Additional Tables}

Table 8: Robustness (I): Effect of School Quality on Voting for Macri (percentage) with no controls

\begin{tabular}{|c|c|c|c|c|c|c|c|c|c|}
\hline \multicolumn{10}{|c|}{ Equations 1 and 2} \\
\hline & \multicolumn{3}{|c|}{ Full Controls } & \multicolumn{3}{|c|}{ School Controls } & \multicolumn{3}{|c|}{ Round and Circuit FE } \\
\hline & $(1)$ & $(2)$ & $(3)$ & $(1)$ & $(2)$ & $(3)$ & (1) & $(2)$ & (3) \\
\hline $\begin{array}{l}\text { Bad Qual. } \\
\text { (BQ) }\end{array}$ & $\begin{array}{l}-0.21^{*} \\
(0.11)\end{array}$ & $\begin{array}{c}-0.50^{* * *} \\
(0.16)\end{array}$ & $\begin{array}{c}-0.52^{* * *} \\
(0.17)\end{array}$ & $\begin{array}{c}-0.21^{*} \\
(0.11)\end{array}$ & $\begin{array}{c}-0.49^{* * *} \\
(0.16)\end{array}$ & $\begin{array}{c}-0.53^{* * *} \\
(0.17)\end{array}$ & $\begin{array}{l}-0.14 \\
(0.10)\end{array}$ & $\begin{array}{c}-0.37^{* * *} \\
(0.15)\end{array}$ & $\begin{array}{c}-0.40^{* * *} \\
(0.16)\end{array}$ \\
\hline $\mathrm{BQ} * \mathrm{UIC}$ & & $\begin{array}{c}0.56^{* * *} \\
(0.22)\end{array}$ & & & $\begin{array}{c}0.54^{* * *} \\
(0.22)\end{array}$ & & & $\begin{array}{c}0.43^{* * *} \\
(0.21)\end{array}$ & \\
\hline $\begin{array}{l}\text { Tot. Effect } \\
\text { (UIC) }\end{array}$ & & $\begin{array}{c}0.03 \\
(0.14)\end{array}$ & & & $\begin{array}{c}0.04 \\
(0.14)\end{array}$ & & & $\begin{array}{c}0.07 \\
(0.14)\end{array}$ & \\
\hline $\mathrm{BQ} * \mathrm{LDC}$ & & & $\begin{array}{c}0.43^{* *} \\
(0.21)\end{array}$ & & & $\begin{array}{c}0.56^{* *} \\
(0.21)\end{array}$ & & & $\begin{array}{c}0.45^{* * *} \\
(0.21)\end{array}$ \\
\hline $\begin{array}{l}\text { Tot. Effect } \\
\text { (LDC) }\end{array}$ & & & $\begin{array}{c}0.02 \\
(0.14)\end{array}$ & & & $\begin{array}{c}0.04 \\
(0.14)\end{array}$ & & & $\begin{array}{c}0.06 \\
(0.14)\end{array}$ \\
\hline Obs. & 12,652 & 12,652 & 12,652 & 12,652 & 12,652 & 12,652 & 12,652 & 12,652 & 12,652 \\
\hline R-Squared & 0.83 & 0.83 & 0.83 & 0.83 & 0.86 & 0.86 & 0.83 & 0.83 & 0.83 \\
\hline
\end{tabular}

Standard Errors clustered at the school level in parentheses

$* * * \mathrm{p}<0.01,{ }^{* *} \mathrm{p}<0.05,{ }^{*} \mathrm{p}<0.1$

Regressions include electoral circuit fixed effects, round fixed effect, school and polling station controls as described in Section 3 .

Definition of the dependent variable: total number of votes for Macri divided by the total number of valid votes (PASO election, first round of the general election and runoff of the general election).

"Upper Income Circuit" (UIC): 1 if the average housing price in the circuit is above the median of the city, 0 otherwise. "Low Density of Children" (LDC): 1 if the average proportion of households with children between 0 and 15 is below the median of the city, 0 otherwise.

Set of control per column: "Full controls" includes electoral circuit fixed effects, round fixed effect, school and polling station controls as described in Section 3. "School Controls" includes electoral circuit fixed effects, round fixed effect, and school controls as described in Section 3. "Round and Circuit FE" includes electoral circuit fixed effects and round fixed effect. 
Table 9: Robustness (II): Effect of School Quality on Voting for Macri (percentage) with no controls

\begin{tabular}{|c|c|c|c|c|c|c|c|c|c|}
\hline \multicolumn{10}{|c|}{ Equations 1 and 2} \\
\hline & \multicolumn{3}{|c|}{ Full Controls } & \multicolumn{3}{|c|}{ School Controls } & \multicolumn{3}{|c|}{ Round and Circuit FE } \\
\hline & (1) & $(2)$ & $(3)$ & (1) & $(2)$ & (3) & (1) & $(2)$ & (3) \\
\hline $\begin{array}{l}\text { Bad Qual. } \\
\text { (BQ) }\end{array}$ & $\begin{array}{l}-0.22^{*} \\
(0.12)\end{array}$ & $\begin{array}{c}-0.53^{* * *} \\
(0.18)\end{array}$ & $\begin{array}{c}-0.60^{* * *} \\
(0.18)\end{array}$ & $\begin{array}{l}-0.22^{*} \\
(0.12)\end{array}$ & $\begin{array}{c}-0.53^{* * *} \\
(0.18)\end{array}$ & $\begin{array}{c}-0.60^{* * *} \\
(0.18)\end{array}$ & $\begin{array}{l}-0.15 \\
(0.11)\end{array}$ & $\begin{array}{c}-0.39^{* *} \\
(0.17)\end{array}$ & $\begin{array}{c}-0.45^{* * *} \\
(0.17)\end{array}$ \\
\hline $\mathrm{BQ} * \mathrm{UIC}$ & & $\begin{array}{c}0.58^{* *} \\
(0.23)\end{array}$ & & & $\begin{array}{c}0.59^{* * *} \\
(0.23)\end{array}$ & & & $\begin{array}{c}0.59^{* *} \\
(0.23)\end{array}$ & \\
\hline $\begin{array}{l}\text { Tot. Effect } \\
\text { (UIC) }\end{array}$ & & $\begin{array}{c}0.05 \\
(0.15)\end{array}$ & & & $\begin{array}{c}0.05 \\
(0.15)\end{array}$ & & & $\begin{array}{c}0.07 \\
(0.15)\end{array}$ & \\
\hline $\mathrm{BQ} * \mathrm{LDC}$ & & & $\begin{array}{c}0.67^{* * *} \\
(0.22)\end{array}$ & & & $\begin{array}{c}0.68^{* * *} \\
(0.22)\end{array}$ & & & $\begin{array}{c}0.53^{* *} \\
(0.22)\end{array}$ \\
\hline $\begin{array}{l}\text { Tot. Effect } \\
\text { (LDC) }\end{array}$ & & & $\begin{array}{c}0.06 \\
(0.14)\end{array}$ & & & $\begin{array}{c}0.07 \\
(0.14)\end{array}$ & & & $\begin{array}{c}0.08 \\
(0.15)\end{array}$ \\
\hline Obs. & 12,652 & 12,652 & 12,652 & 12,652 & 12,652 & 12,652 & 12,652 & 12,652 & 12,652 \\
\hline R-Squared & 0.83 & 0.83 & 0.83 & 0.83 & 0.86 & 0.86 & 0.83 & 0.83 & 0.83 \\
\hline
\end{tabular}

Standard Errors clustered at the school level in parentheses

*** $\mathrm{p}<0.01,{ }^{* *} \mathrm{p}<0.05,{ }^{*} \mathrm{p}<0.1$

Regressions include electoral circuit fixed effects, round fixed effect, school and polling station controls as described in Section 3.

Definition of the dependent variable: total number of votes for Macri divided by the total number of valid votes (first round of the general election and runoff of the general election). Total number of votes for Macri or any other candidate in the Cambiemos Alliance divided by the total number of valid votes (PASO election).

"Upper Income Circuit" (UIC): 1 if the average housing price in the circuit is above the median of the city, 0 otherwise. "Low Density of Children" (LDC): 1 if the average proportion of households with children between 0 and 15 is below the median of the city, 0 otherwise.

Set of control per column: "Full controls" includes electoral circuit fixed effects, round fixed effect, school and polling station controls as described in Section 3. "School Controls" includes electoral circuit fixed effects, round fixed effect, and school controls as described in Section 3. "Round and Circuit FE" includes electoral circuit fixed effects and round fixed effect. 
Table 10: Effect of School Quality on Voting for Macri by four quality levels of school infrastructure (percentage)

\begin{tabular}{|c|c|c|c|c|}
\hline \multicolumn{5}{|c|}{ Equations 1 and 2} \\
\hline & \multicolumn{2}{|c|}{ (A) } & \multicolumn{2}{|c|}{ (B) } \\
\hline & $(1)$ & $(2)$ & $(1)$ & $(2)$ \\
\hline Very Bad Quality & $\begin{array}{l}-0.47^{*} \\
(0.25)\end{array}$ & $\begin{array}{c}-0.86^{* * *} \\
(0.36)\end{array}$ & $\begin{array}{c}-0.56^{* *} \\
(0.27)\end{array}$ & $\begin{array}{c}-1.03^{* * *} \\
(0.37)\end{array}$ \\
\hline Very Bad Quality * Upper Income Circuit & & $\begin{array}{c}0.73 \\
(0.51)\end{array}$ & & $\begin{array}{c}0.87^{*} \\
(0.52)\end{array}$ \\
\hline Very Bad Quality Total Effect (Upper Income Circuits) & & $\begin{array}{l}-0.12 \\
(0.36)\end{array}$ & & $\begin{array}{l}-0.15 \\
(0.35)\end{array}$ \\
\hline Bad Quality & $\begin{array}{l}-0.29 \\
(0.18)\end{array}$ & $\begin{array}{c}-0.67^{* * *} \\
(0.30)\end{array}$ & $\begin{array}{l}-0.30 \\
(0.19)\end{array}$ & $\begin{array}{c}-0.77^{* *} \\
(0.30)\end{array}$ \\
\hline Bad Quality * Upper Income Circuit & & $\begin{array}{c}0.67^{* *} \\
(0.30)\end{array}$ & & $\begin{array}{c}0.83^{* *} \\
(0.39)\end{array}$ \\
\hline Bad Quality Total Effect (Upper Income Circuits) & & $\begin{array}{c}0.002 \\
(0.002)\end{array}$ & & $\begin{array}{c}0.05 \\
(0.24)\end{array}$ \\
\hline Good Quality & $\begin{array}{l}-0.14 \\
(0.16)\end{array}$ & $\begin{array}{l}-0.26 \\
(0.28)\end{array}$ & $\begin{array}{l}-0.16 \\
(0.18)\end{array}$ & $\begin{array}{l}-0.36 \\
(0.29)\end{array}$ \\
\hline Good Quality * Upper Income Circuit & & $\begin{array}{c}0.19 \\
(0.36)\end{array}$ & & $\begin{array}{c}0.33 \\
(0.38)\end{array}$ \\
\hline Good Quality Total Effect (Upper Income Circuits) & & $\begin{array}{l}-0.006 \\
(0.002)\end{array}$ & & $\begin{array}{l}-0.03 \\
(0.23)\end{array}$ \\
\hline Obs. & 12,626 & 12,626 & 12,626 & 12,626 \\
\hline R-Squared & 0.92 & 0.92 & 0.92 & 0.92 \\
\hline
\end{tabular}

Standard Errors clustered at the school level in parentheses

*** $\mathrm{p}<0.01,{ }^{* *} \mathrm{p}<0.05,{ }^{*} \mathrm{p}<0.1$

Regressions include electoral circuit fixed effects, round fixed effect, school and polling station controls as described in Section 3 .

(A): Definition of the dependent variable: total number of votes for Macri divided by the total number of valid votes (PASO election, first round of the general election and runoff of the general election).

(B): Definition of the dependent variable: total number of votes for Macri divided by the total number of valid votes (first round of the general election and runoff of the general election). Total number of votes for Macri or any other candidate in the Cambiemos Alliance divided by the total number of valid votes (PASO election).

"Upper Income Circuit": 1 if the average housing price in the circuit is above the median of the city, 0 otherwise. 
Table 11: Effect of School Quality on Voting for Macri by four quality levels of school infrastructure (percentage)

\begin{tabular}{|c|c|c|c|c|}
\hline \multicolumn{5}{|c|}{ Equations 1 and 2} \\
\hline & \multicolumn{2}{|c|}{ (A) } & \multicolumn{2}{|c|}{ (B) } \\
\hline & $(1)$ & $(2)$ & $(1)$ & $(2)$ \\
\hline Very Bad Quality & $\begin{array}{l}-0.47^{*} \\
(0.25)\end{array}$ & $\begin{array}{c}-1.05^{* * *} \\
(0.37)\end{array}$ & $\begin{array}{c}-0.56^{* *} \\
(0.27)\end{array}$ & $\begin{array}{c}-1.22^{* * *} \\
(0.37)\end{array}$ \\
\hline Very Bad Quality * Low Density of Children & & $\begin{array}{l}1.06^{* *} \\
(0.51)\end{array}$ & & $\begin{array}{c}1.22^{* *} \\
(0.51)\end{array}$ \\
\hline Very Bad Quality Total Effect (LDC) & & $\begin{array}{c}0.02 \\
(0.35)\end{array}$ & & $\begin{array}{l}-0.05 \\
(0.35)\end{array}$ \\
\hline Bad Quality & $\begin{array}{l}-0.29 \\
(0.18)\end{array}$ & $\begin{array}{c}-0.78^{* *} \\
(0.30)\end{array}$ & $\begin{array}{l}-0.30 \\
(0.19)\end{array}$ & $\begin{array}{c}-0.86^{* * *} \\
(0.31)\end{array}$ \\
\hline Bad Quality * Low Density of Children & & $\begin{array}{c}0.76^{* *} \\
(0.37)\end{array}$ & & $\begin{array}{c}0.87^{* *} \\
(0.39)\end{array}$ \\
\hline Bad Quality Total Effect (LDC) & & $\begin{array}{c}-0.002 \\
(0.20)\end{array}$ & & $\begin{array}{l}0.006 \\
(0.24)\end{array}$ \\
\hline Good Quality & $\begin{array}{l}-0.14 \\
(0.16)\end{array}$ & $\begin{array}{l}-0.40 \\
(0.29)\end{array}$ & $\begin{array}{l}-0.16 \\
(0.18)\end{array}$ & $\begin{array}{l}-0.43 \\
(0.29)\end{array}$ \\
\hline Good Quality * Low Density of Children & & $\begin{array}{c}0.36 \\
(0.36)\end{array}$ & & $\begin{array}{c}0.37 \\
(0.37)\end{array}$ \\
\hline Good Quality Total Effect (LDC) & & $\begin{array}{c}-0.003 \\
(0.2)\end{array}$ & & $\begin{array}{l}-0.005 \\
(0.222)\end{array}$ \\
\hline Obs. & 12,626 & 12,626 & 12,626 & 12,626 \\
\hline R-Squared & 0.92 & 0.92 & 0.92 & 0.92 \\
\hline
\end{tabular}

Standard Errors clustered at the school level in parentheses

*** $\mathrm{p}<0.01,{ }^{* *} \mathrm{p}<0.05,{ }^{*} \mathrm{p}<0.1$

Regressions include electoral circuit fixed effects, round fixed effect, school and polling station controls as described in Section 3 .

(A): Definition of the dependent variable: total number of votes for Macri divided by the total number of valid votes (PASO election, first round of the general election and runoff of the general election).

(B): Definition of the dependent variable: total number of votes for Macri divided by the total number of valid votes (first round of the general election and runoff of the general election). Total number of votes for Macri or any other candidate in the Cambiemos Alliance divided by the total number of valid votes (PASO election).

"Low Density of Children": 1 if the average proportion of households with children between 0 and 15 is below the median of the city, 0 otherwise. 